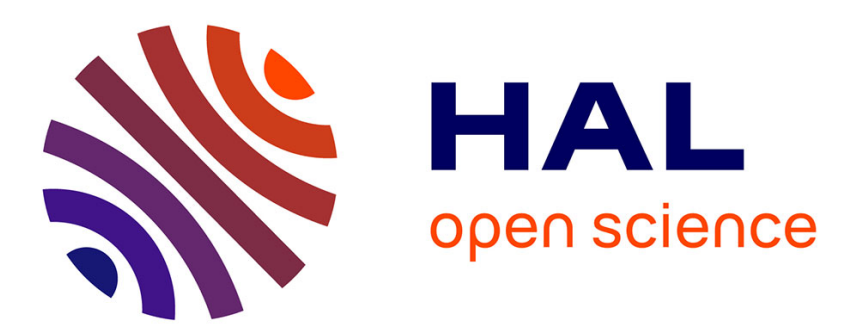

\title{
Photochemical processes observed during the reaction of superoxide reductase from Desulfoarculus baarsii with superoxide: re-evaluation of the reaction mechanism.
}

Florence Bonnot, Chantal Houée-Levin, Vincent Favaudon, Vincent Nivière

\section{- To cite this version:}

Florence Bonnot, Chantal Houée-Levin, Vincent Favaudon, Vincent Nivière. Photochemical processes observed during the reaction of superoxide reductase from Desulfoarculus baarsii with superoxide: re-evaluation of the reaction mechanism.. Biochimica et Biophysica Acta (BBA) - Enzymology, 2010, 1804, pp.762-7. 10.1016/j.bbapap.2009.11.019 . hal-01075296

\author{
HAL Id: hal-01075296 \\ https://hal.science/hal-01075296
}

Submitted on 7 Jan 2015

HAL is a multi-disciplinary open access archive for the deposit and dissemination of scientific research documents, whether they are published or not. The documents may come from teaching and research institutions in France or abroad, or from public or private research centers.
L'archive ouverte pluridisciplinaire HAL, est destinée au dépôt et à la diffusion de documents scientifiques de niveau recherche, publiés ou non, émanant des établissements d'enseignement et de recherche français ou étrangers, des laboratoires publics ou privés. 


\section{Photochemical processes observed during the reaction of superoxide reductase from Desulfoarculus baarsii with superoxide. Re-evaluation of the reaction mechanism.}

Florence Bonnot ${ }^{\mathrm{a}}$, Chantal Houée-Levin ${ }^{\mathrm{b}}$, Vincent Favaudon ${ }^{\mathrm{c}}$, Vincent Nivière ${ }^{\mathrm{a}, *}$

${ }^{a}$ Laboratoire de Chimie et Biologie des Métaux, iRTSV-CEA Grenoble/CNRS/Université Joseph Fourier, 17 Avenue des Martyrs, 38054 Grenoble Cedex 9, France.

${ }^{\text {b }}$ Laboratoire de Chimie Physique, UMR8000 CNRS/Université Paris-Sud, Bâtiment 350, Centre Universitaire 91405 Orsay Cedex, France

c Inserm Unité 612 and Institut Curie, Bâtiment 110-112, Centre Universitaire 91405 Orsay Cedex, France

* Corresponding author. Laboratoire de Chimie et Biologie des Métaux, iRTSV-CEA Grenoble/CNRS/Université Joseph Fourier, 17 Avenue des Martyrs, 38054 Grenoble Cedex 9, France. Tel: 334387891 09; Fax: 33438789124 ; E.mail: vniviere@cea.fr

Keywords: superoxide reductase, pulse radiolysis, reaction intermediates, photochemical processes, Desulfoarculus baarsii.

Abbreviations. SOR, superoxide reductase; SOD, superoxide dismutase. 


\section{Abstract}

Superoxide reductase SOR is an enzyme involved in superoxide detoxification in some microorganisms. Its active site consists of a non-heme ferrous center in an unusual $\left[\mathrm{Fe}(\mathrm{NHis})_{4}\right.$ $(\mathrm{SCys})_{1}$ ] square pyramidal pentacoordination that efficiently reduces superoxide into hydrogen peroxide. In previous works, the reaction mechanism of the SOR from Desulfoarculus baarsii enzyme, studied by pulse radiolysis, was shown to involve the formation of two reaction intermediates $\mathrm{T} 1$ and $\mathrm{T} 2$. However, the absorption spectrum of $\mathrm{T} 2$ was reported with an unusual sharp band at $625 \mathrm{~nm}$, very different from that reported for other SORs. In this work, we show that the sharp band at $625 \mathrm{~nm}$ observed by pulse radiolysis reflects the presence of photochemical processes that occurs at the level of the transient species formed during the reaction of SOR with superoxide. These processes do not change the stoichiometry of the global reaction. These data highlight remarkable photochemical properties for these reaction intermediates, not previously suspected for iron-peroxide species formed in the SOR active site. We have reinvestigated the reaction mechanism of the SOR from Desulfoarculus baarsii by pulse radiolysis in the absence of these photochemical processes. The $\mathrm{T} 1$ and $\mathrm{T} 2$ intermediates now appear to have absorption spectra similar to those reported for the Archaeoglobus fulgidus SOR enzymes. Although for some enzymes of the family only one transient was reported, on the whole, the reaction mechanisms of the different SORs studied so far seem very similar, which is in agreement with the strong sequence and structure homologies of their active sites. 


\section{Introduction}

Superoxide radical, $\mathrm{O}_{2}{ }^{--}$, is at the same time a very toxic by-product and a defence agent coming from the oxygen metabolism. It forms from the adventitious one electron reduction of $\mathrm{O}_{2}$ at the level of the respiratory chain, by autooxidation of some small molecules or protein cofactors and by the NADPH oxidase system [1,2]. Cells possess very efficient enzymatic systems that can regulate the steady state of superoxide radical concentration [1, 2]. For decades, it was thought that superoxide dismutase (SOD), which catalyzes the disproportionation of superoxide into $\mathrm{H}_{2} \mathrm{O}_{2}$ and $\mathrm{O}_{2}$, was the only existing superoxide detoxification enzyme. More recently, it has been discovered that some anaerobic or microaerophilic bacteria use a totally different enzyme system to detoxify superoxide. The enzyme was called superoxide reductase (SOR), which catalyzes the one-electron reduction of $\mathrm{O}_{2}{ }^{--}$to $\mathrm{H}_{2} \mathrm{O}_{2}[3-8]$ :

$$
\mathrm{O}_{2}^{\bullet-}+1 \mathrm{e}^{-}+2 \mathrm{H}^{+} \rightarrow \mathrm{H}_{2} \mathrm{O}_{2}
$$

SORs are non-heme iron proteins that can be classified into one-iron proteins, which contain only the iron active-site center (Center II) $[3,5,9,10]$ or two-iron proteins $[4,6,11]$, which possess an additional rubredoxin-like $\left[\mathrm{Fe}^{3+}-(\mathrm{SCys})_{4}\right]$, center (Center I), apparently not involved in catalysis [12]. The SOR active site consists of a non-heme $\mathrm{Fe}^{2+}$ center in an unusual $\left[\mathrm{Fe}(\mathrm{NHis})_{4}(\mathrm{SCys})_{1}\right]$ square pyramidal pentacoordination [13, 14], with a vacant coordination position. It reacts specifically at nearly diffusion-controlled rates with $\mathrm{O}_{2}{ }^{--}$and, according to an inner sphere $\mathrm{O}_{2}{ }^{-}$ reduction mechanism, leads to $\mathrm{H}_{2} \mathrm{O}_{2}$ as final product. The resulting ferric active site becomes hexacoordinated after binding to the carboxylate side chain of a well conserved glutamate residue $[13,15]$ and can be regenerated into its reduced and active form by cellular reductases, allowing turn-overs with superoxide [16]. Different groups have investigated the reaction mechanism of SOR with superoxide by rapid kinetics, mainly using pulse radiolysis technique [6, 11, 17-22]. Although one or two reaction intermediates have been proposed depending on the enzyme studied, it is now 
generally accepted that at least one transient species is a $\mathrm{Fe}^{3+}$-peroxide species. This is strongly supported by studies on SOR variants, which stabilize these iron-peroxide species and have allowed their detailed characterization by Resonance Raman spectroscopies [23-25] and X-ray diffractions techniques [26].

The SOR from Desulfoarculus baarsii enzyme has been studied by pulse radiolysis and the reaction mechanism was proposed to involve the formation of two intermediates $\mathrm{T} 1$ and $\mathrm{T} 2[17,19$, 25].

$$
\mathrm{SOR}_{\mathrm{red}}+\mathrm{O}_{2}^{\cdot-} \underset{k_{1}}{\rightarrow} \mathrm{T} 1 \underset{k_{2}}{\stackrel{+H^{+}}{\rightarrow}} \mathrm{T} 2 \underset{k_{3}}{\stackrel{+H^{+}}{\rightarrow}} \mathrm{SOR}_{\mathrm{ox}}+\mathrm{H}_{2} \mathrm{O}_{2}
$$

The first transient $\mathrm{T} 1$ presents an absorption spectrum very similar to that reported on other SORs and was described as a $\mathrm{Fe}^{3+}$-peroxo species $\left(\mathrm{Fe}^{3+}-\mathrm{OO}^{-}\right)$, resulting from the bimolecular reaction of $\mathrm{O}_{2}{ }^{\bullet-}$ with $\mathrm{Fe}^{2+}$. T2 is formed after a protonation of $\mathrm{T} 1$, thus it was proposed to be a $\mathrm{Fe}^{3+}$ hydroperoxo species $\left(\mathrm{Fe}^{3+}-\mathrm{OOH}\right)$. Conversely to other SORs, the absorption spectrum of $\mathrm{T} 2$ in the D. baarsii enzyme seemed to involve a sharp band at $625 \mathrm{~nm}$ very different from that reported for other SORs. Finally, althought the kinetic of T2 evolution could not be observed with the device used in these studies, T2 was proposed to undergo a second protonation process to generate $\mathrm{H}_{2} \mathrm{O}_{2}$ and the $\mathrm{Fe}^{3+}$ final species $[19,25]$.

In this work, we show that for the $D$. baarsii enzyme the sharp band at $625 \mathrm{~nm}$ observed by pulse radiolysis reflects the presence of a photochemical process that occurs at the level of a transient species formed during the reaction of SOR with $\mathrm{O}_{2}{ }^{\circ-}$. We have reinvestigated the reaction mechanism of the SOR from D. baarsii by pulse radiolysis in the absence of this photochemical process. 


\section{Materials and methods}

\subsection{Protein expression and purification}

Overexpression and purification of the recombinant SOR wild-type from D. baarsii was carried out as reported in [4]. The protein was isolated with a fully oxidized Center I $\left(\varepsilon_{503 \mathrm{~nm}}=4,400\right.$ $\left.\mathrm{M}^{-1} \mathrm{~cm}^{-1}\right)$ and a fully reduced Center II. Center II can be fully oxidized $\left(\varepsilon_{644 \mathrm{~nm}}=1,900 \mathrm{M}^{-1} \mathrm{~cm}^{-1}\right)$ with a slight stoechiometric excess of $\mathrm{K}_{2} \mathrm{IrCl}_{6}$ [19].

\subsection{Pulse radiolysis and spectrophotometric experiments}

Pulse radiolysis measurements were performed as described elsewhere [27]. Sodium formate and buffers were of the highest quality available. Oxygen was from ALPHA GAZ, with purity higher than 99.99\%. Water was purified using a Millipore Milli-Q system (resistivity $18.2 \mathrm{M} \Omega$ ). Briefly, free radicals were generated by irradiation of $\mathrm{O}_{2}$-saturated aqueous protein solutions (100 $\mu \mathrm{M}$ ), in $2 \mathrm{mM}$ buffer, $10 \mathrm{mM}$ sodium formate with $0.2-2 \mu$ s pulses of $4 \mathrm{MeV}$ electrons at the linear accelerator at the Curie Institute, Orsay, France. Superoxide anion, $\mathrm{O}_{2}{ }^{\bullet-}$, was generated during the scavenging by formate of the radiolytically produced hydroxyl radical, $\mathrm{HO}^{\bullet}$, as previously described [28]. The doses per pulse were calibrated from the absorption of the thiocyanate radical $(\mathrm{SCN})_{2}{ }^{--}$obtained by radiolysis of the thiocyanate ion in $\mathrm{N}_{2} \mathrm{O}$-saturated solution $\left(\left[\mathrm{SCN}^{-}\right]=10^{-2} \mathrm{M}\right.$, $\left.\mathrm{G}\left((\mathrm{SCN})_{2}{ }^{-}\right)=0.55 \mu \mathrm{mol} . \mathrm{J}^{-1}, \varepsilon_{472 \mathrm{~nm}}=7580 \mathrm{M}^{-1} \mathrm{~cm}^{-1}\right)$ [29]. The dose varies linearly with the pulse length, for instance a dose of ca. 5 Gy per pulse $\left(0.2 \mu\right.$ s long) resulted in ca. $2.8 \mu \mathrm{M}$ of $\mathrm{O}_{2}{ }^{\bullet-}$. Reactions were followed spectrophotometrically, using an Hamamatsu SuperQuiet Xenon-Mercury lamp $\left(150 \mathrm{~W}\right.$, between 310 and $750 \mathrm{~nm}$ ) or a tungsten lamp (between 450 and $750 \mathrm{~nm}$ ), at $20{ }^{\circ} \mathrm{C}$ in a $2 \mathrm{~cm}$ path length fused silica cuvette. The Xenon lamp was not submitted to a surtension to increase its power. A cut-off filter cutting all wavelengths below 310, 345, 395, 425 or $530 \mathrm{~nm}$, was 
positioned between the lamp and the cuvette. Kinetic traces were analyzed using a LevenbergMarquardt algorithm from the Kaleidagraph ${ }^{\circledR}$ software package (Synergy Software). The absorption spectrum of T2 was calculated from the double exponential fits of the kinetic traces between 0.3 and $30 \mathrm{~ms}$ at different wavelengths: $\mathrm{A}=\mathrm{A}_{1} \exp \left(-k_{2} * \mathrm{t}\right)+\mathrm{A}_{2} \exp \left(-k_{3} * \mathrm{t}\right)+\mathrm{A}_{3}$, where : $\mathrm{A}$, absorbance at time $\mathrm{t} ; \mathrm{A}_{1}$ and $\mathrm{A}_{2}$, pre-exponential terms which describe the amplitude of each phase with $k_{2}$ and $k_{3}$ values fixed at 255 and $110 \mathrm{~s}^{-1}$, respectively; $\mathrm{A}_{3}$, absorbance at the end of the reaction. $\mathrm{A}_{2}+\mathrm{A}_{3}$ corresponds to the absorbance of $\mathrm{T} 2$ at a specific wavelength.

Optical absorbance measurements were made using a Varian Cary spectrophotometer, in 1 cm path length cuvette. Light-induced absorbance changes (flash photolysis) were measured with a laboratory-built spectrophotometer similar to the one developed by Joliot et al [30]. The absorption level is sampled using $2 \mu$ s monochromatic Xenon flashes given from $1 \mathrm{~ms}$ to several seconds after actinic excitation.

\subsection{Analytical experiments}

Electrospray ionization mass spectra were obtained on a Perkin-Elmer Sciex API III+ triple quadrupole mass spectrometer equipped with a nebulizer-assisted electrospray source operating at atmospheric pressure. Samples were in $10 \mathrm{mM}$ ammonium acetate.

Hydrogen peroxide production was determined immediately after the pulse radiolysis using the leuco crystal violet horseradish peroxidase method as described in [31]. 


\section{Results}

\subsection{Photochemical processes associated with the pulse radiolysis experiments}

The reaction mechanism of the SOR from Desulfoarculus baarsii with superoxide has been previously investigated by pulse radiolysis, using a Xenon lamp to detect the very fast SOR absorbance variations during its reaction with superoxide $[17,19,25]$, which is a common procedure. In all these studies, a $310 \mathrm{~nm}$ cut-off filter was positioned between the lamp and the UVvis cuvette containing the SOR sample in order to prevent possible alteration of aromatic amino acid residues during the measurement.

Here, similar pulse radiolysis experiments with the SOR from Desulfoarculus baarsii were repeated at pH 7.6, but with various cut-off filters, cutting below 345, 395, 425 or $530 \mathrm{~nm}$, between the Xenon lamp and the cuvette. The kinetics of the formation of the first reaction intermediate T1 remained unchanged whatever the filters. It is second order with respect to SOR and superoxide, with a rate constant $k_{l}=(1.0 \pm 0.2) 10^{9} \mathrm{M}^{-1} \mathrm{~s}^{-1}$ (data not shown), consistent with a stoichiometric reaction of SOR with $\mathrm{O}_{2}{ }^{-}$, as previously described [17, 19]. As shown in Figure 1, with the $345 \mathrm{~nm}$ filter, the absorption spectrum of T1 between 330 and $670 \mathrm{~nm}$ still exhibits a broad absorbance band centered at $600 \mathrm{~nm}$, with a similar shape to that of the first intermediate obtained with the $310 \mathrm{~nm}$ filter. However with the $345 \mathrm{~nm}$ filter, T1 presents a 1.6 fold lower epsilon value at $600 \mathrm{~nm}$ compared to that obtained with the $310 \mathrm{~nm}$ filter.

Surprisingly, in the presence of the $345,395,425$ or $530 \mathrm{~nm}$ filters, the amplitudes and the kinetics of the traces recorded at longer timescales corresponding to the decay of T1 are modified compared to those obtained with the $310 \mathrm{~nm}$ filter (Figure 2 and not shown). These modifications are visible at various wavelengths in the range of 600 to $650 \mathrm{~nm}$. The effects of the $345 \mathrm{~nm}$ or above filters $(395,425$ or $530 \mathrm{~nm}$ filters) are identical at all the wavelengths studied every 5 to 10 
$\mathrm{nm}$ between 400 and $720 \mathrm{~nm}$ (Figure 2 and data not shown) and in the following are presented only the experiments carried out in the presence of the $345 \mathrm{~nm}$ filter.

As previously reported, in the presence of the $310 \mathrm{~nm}$ filter, at all the wavelength investigated between 450 and $700 \mathrm{~nm}$, the decay of the first intermediate was found to be monoexponential, with a rate constant of $500 \mathrm{~s}^{-1}$ at $\mathrm{pH} 7.6$, to form a second reaction intermediate exhibiting a sharp absorption band at $625 \mathrm{~nm}$ ([19] and Figure 3). This sharp absorbance band remained observable up to about $50 \mathrm{~ms}$ reaction time. However, because of the Xenon lamp instability, the kinetic of its evolution could not be investigated [17, 19]. Now, in the presence of the $345 \mathrm{~nm}$ filter, the decay of T1 is more complex with two phases. The amplitude of these two phases are clearly visible using pulses generating $9 \mu \mathrm{M}$ of $\mathrm{O}_{2}{ }^{--}$(Figure 2). All the traces between 450 and $650 \mathrm{~nm}$ could be adjusted with a biexponential model with rate constants of $255 \pm 27 \mathrm{~s}^{-1}$ $\left(k_{2}\right)$ and $110 \pm 24 \mathrm{~s}^{-1}\left(k_{3}\right)$, respectively (Figure 2). Both rate constants $k_{2}$ and $k_{3}$ were found to be independent of SOR concentration (data not shown). These data suggest that in the presence of the $345 \mathrm{~nm}$ filter, the decay of T1 conducts to the formation of two successive species $\mathrm{T} 2$ and $\mathrm{T} 3$. The absorption spectrum of $\mathrm{T} 2$, which cannot be experimentally determined since $\mathrm{T} 2$ evolves toward $\mathrm{T} 3$ before its maximal formation, was reconstituted by an extrapolation of the decay of T1 using the double exponential fits of the kinetic traces at different wavelengths. As shown in Figure 3, T2 exhibits a broad band centered at about $570 \mathrm{~nm}$, which looks like the spectrum of an oxidized SOR in basic medium corresponding to a $\mathrm{Fe}^{3+}-\mathrm{OH}$ species [32]. The absorption spectrum of $\mathrm{T} 3$, which is formed maximally $20 \mathrm{~ms}$ after the beginning of the reaction, can be reconstructed directly from the observed absorption value at the different wavelengths. As shown in Figure 3, this spectrum is identical to that of SOR oxidized by superoxide $9 \mu \mathrm{M}$. It does not exhibit the sharp absorbance band centered at $625 \mathrm{~nm}$ observed with the $310 \mathrm{~nm}$ filter. These data show that in the presence of the 345 $\mathrm{nm}$ filter, T3 is the final expected reaction product, $i$. e. ferric SOR, resulting from a stoichiometric oxidation of SOR by $\mathrm{O}_{2}{ }^{-*}$. 
These results suggest that the sharp absorption band at $625 \mathrm{~nm}$ observed at the level of T2 during the reaction time of SOR with superoxide in the presence of the $310 \mathrm{~nm}$ filter can be directly associated with the Xenon lamp illumination, at wavelengths between 310 and $345 \mathrm{~nm}$. This thin band might arise from a photochemical process induced by the Xenon lamp, which targets a sensitive absorption band in the region 310-345 nm.

\subsection{Reaction products in the presence or absence of the photochemical process}

In order to determine if the photochemical process observed during the pulse radiolysis experiments induces some modifications on the overall reaction, a SOR solution was allowed to react with $16.5 \mu \mathrm{M}$ of superoxide produced by pulse radiolysis (26.5 Gy) and illuminated with the Xenon lamp. An absorption spectrum of the solution was taken within a minute after the pulse with a classical UV-vis spectrophotometer. A catalytical amount of catalase was added to the solution before the pulse in order to avoid any possible oxidation of SOR by $\mathrm{H}_{2} \mathrm{O}_{2}$ generated at the end of the reaction. In all cases, in the presence of the 310 or $345 \mathrm{~nm}$ cut off filters, the solution exhibited the final spectrum characteristic of an oxidized SOR at $16.5 \mu \mathrm{M}$ (band at $644 \mathrm{~nm}$ ), in agreement with a stoichiometric oxidation of SOR by $\mathrm{O}_{2}{ }^{--}$(Figure 3). This oxidized SOR was still redox active since it could be reversibly reduced and re-oxidized with stoichiometric amounts of ascorbate and iridium chloride, respectively (data not shown). In addition, electrospray mass spectra analysis of SOR did not reveal any alteration of the mass of the SOR polypeptide chain whatever the presence of a 310 or a $345 \mathrm{~nm}$ cut-off filter in the pulse radiolysis experiments $(14,022 \pm 2 \mathrm{Da}$, data not shown).

Quantification of $\mathrm{H}_{2} \mathrm{O}_{2}$ production immediately after the pulse was carried out in similar experimental conditions, except that no catalase was present in the pulsed solutions. Irradiation of aqueous solutions always leads to some $\mathrm{H}_{2} \mathrm{O}_{2}$ production during the primary steps of water radiolysis $\left(\mathrm{G} \approx 0.07 \mu \mathrm{mol} \mathrm{\textrm {J } ^ { - 1 }}\right)$ [33]. Here the dose was equal to $26.5 \mathrm{~Gy}$, hence the radiolytic $\left[\mathrm{H}_{2} \mathrm{O}_{2}\right]$ 
was equal to $1.8 \mu \mathrm{M}$. Taking into account the correction of the radiolytic $\mathrm{H}_{2} \mathrm{O}_{2}$, in the presence of the 310 or the $345 \mathrm{~nm}$ cut off filter, $10.5 \pm 1.2$ or $13.6 \pm 0.3 \mu \mathrm{M}$ of $\mathrm{H}_{2} \mathrm{O}_{2}$ were detected immediately after the pulse, respectively. These data suggest that in the presence of the $345 \mathrm{~nm}$ filter, $\mathrm{H}_{2} \mathrm{O}_{2}$ quantification fits quite well to the expected value for a stoichiometric oxidation of $\mathrm{SOR}$ by $\mathrm{O}_{2}{ }^{--}$ $(16.5 \mu \mathrm{M})^{1}$. In the presence of the $310 \mathrm{~nm}$ filter, the $\mathrm{H}_{2} \mathrm{O}_{2}$ production is slightly lower, but still indicates that most of the superoxide reacting with SOR is converted into $\mathrm{H}_{2} \mathrm{O}_{2}$.

On the whole, these data show that the photochemical process observed during the reaction cycle of SOR can be associated to a transient photoproduct (absorbance band at $625 \mathrm{~nm}$ ) which does not markedly affect the overall reaction of SOR with $\mathrm{O}_{2}{ }^{\circ}$.

\subsection{Photochemical properties of the SOR reaction intermediates}

In order to determine if the photochemical process can be specifically associated with a SOR transient or with SOR by itself, the following experiments were carried out.

First, during the pulse radiolysis experiments, no absorbance variations at $625 \mathrm{~nm}$ were observed from a solution which did not contain SOR. This shows that the $625 \mathrm{~nm}$ band is not associated with an instrumental artifact.

Second, the pulse radiolysis experiments were realised with increasing radiation doses to generate 3,5 or $9 \mu \mathrm{M}$ of superoxide, in the presence of an excess of SOR with the 310 or $345 \mathrm{~nm}$ filter. The absorbance was recorded at $625 \mathrm{~nm} 20 \mathrm{~ms}$ after the pulse (maximum of the sharp absorption band). The $625 \mathrm{~nm}$ absorbance values were found to be directly proportional to the amount of superoxide generated by pulse radiolysis in both cases (Figure 4). As shown in Figure 4, the slope is higher with the filter cutting off at $310 \mathrm{~nm}$ compared to that with the filter at $345 \mathrm{~nm}$, reflecting a higher $\varepsilon$ value at $625 \mathrm{~nm}$ for the species formed in the presence of that filter. These data confirm that the $625 \mathrm{~nm}$ sharp band is associated with the reaction of SOR with superoxide.

\footnotetext{
${ }^{1}$ The precision on the irradiation doses are $\pm 10 \%$.
} 
Third, as a control, flash photolysis experiments with a Xenon lamp on both the ferrous and ferric forms of SOR, in the absence of superoxide, were carried out. A SOR sample (10 $\mu \mathrm{M}$ SOR, $10 \mathrm{mM}$ formate, $10 \mathrm{mM}$ Tris/HCl $\mathrm{pH}$ 7.6) was irradiated with a pulsed Xenon lamp in the presence of three different cut-off filters at 305,345 and $390 \mathrm{~nm}$. The signal was recorded at $625 \mathrm{~nm}$ as a function of time, $1 \mathrm{~ms}$ after the Xenon flash and up to $1 \mathrm{~s}$. For the ferrous SOR as well as the ferric SOR tested by flash photolysis with cut-off filters at 305, 345 and $390 \mathrm{~nm}$, no signals were detected at $625 \mathrm{~nm}$ between $1 \mathrm{~ms}$ to $1 \mathrm{~s}$ after the Xenon flash (data not shown). These data support the fact that the stable ferrous and ferric forms of SOR are not at the origin of the photochemical process observed during the pulse radiolysis experiments. Consequently, the photochemical process can be specifically associated with an intermediate formed during the reaction of SOR with superoxide.

\subsection{Effect of the lamp, Xenon/tungsten, on the photochemical process}

The pulse radiolysis experiments have been repeated with a tungsten lamp instead of the Xenon one. With the tungsten lamp, which is less intense than the Xenon lamp, the short time kinetics $(0-500 \mu \mathrm{s})$ could not be investigated. This lamp can be only used to follow kinetics above 0.5-1 ms, which in the case of SOR corresponds to those described by the rate constants $k_{2}$ and $k_{3}$. In addition, whereas the Xenon lamp emits down to $250 \mathrm{~nm}$, the emission spectrum of the tungsten lamp strongly decreases below $500 \mathrm{~nm}$. With the tungsten lamp, the kinetic traces are not affected by the presence or the absence of the 310 to $425 \mathrm{~nm}$ cut off filters (data not shown) and are identical to those obtained with the Xenon lamp in the presence of the $345 \mathrm{~nm}$ and above filters. The spectrum of the final species reconstructed at $20 \mathrm{~ms}$ reaction time was identical to that obtained with the Xenon lamp in the presence of the 345 to 425 cut off filters (data not shown). These data are in agreement with a photochemical process that concerns only the transient species that exhibits absorption band(s) peaking below $345 \mathrm{~nm}$. 


\section{Discussion}

The interpretation of the rapid kinetic data obtained by pulse radiolysis on SOR are essentially based on the characterisation of the spectra of the different reactions intermediates formed during one turn over reaction of SOR with superoxide. Three different groups, including ours, have investigated the reaction mechanism of SOR with superoxide by pulse radiolysis. Depending on the origin of SOR, one or two reaction intermediates have been observed $[6,11,17$ $21,25]$. In all the studies published so far, the spectra of the first observed reaction intermediate are very similar, with a broad band centered at $600-610 \mathrm{~nm}$. This intermediate $\mathrm{T} 1$ was generally proposed to be a ferric iron (hydro)peroxo species, resulting from the fast binding of superoxide to the sixth open coordination sphere of the ferrous iron with simultaneous electron transfer to the superoxide adduct. Afterwards, depending on the enzyme studied, different observations have been made, suggesting that different reaction mechanisms could exist among SOR enzymes. In the case of the enzymes from Archaeoglobus fulgidus, a second reaction intermediate T2 has been observed and from its absorption spectrum was convincingly attributed to a $\mathrm{Fe}^{3+}-\mathrm{OH}$ species $[11,20]$. This $\mathrm{Fe}^{3+}-\mathrm{OH}$ species would result from a nucleophilic attack of a water molecule to the iron hydroperoxide species to generate the reaction product $\mathrm{H}_{2} \mathrm{O}_{2}$. In a last phase, the carboxylate side chain of the well conserved Glu47 residue would bind to the iron in place of the hydroxide ligand to make the resting ferric state of the enzyme. In the case of the SOR from $D$. vulgaris, no evidence for the formation of a second reaction intermediate was reported and the iron peroxide intermediate species $\mathrm{T} 1$ is apparently directly transformed to the ferric-Glu SOR species and $\mathrm{H}_{2} \mathrm{O}_{2}$ product [6, 18]. In the case of the enzyme from D. baarsii, a second intermediate was also observed. However, it exhibited a different spectrum than that characterized for the A. fulgidus enzymes, with a remarkable sharp absorption band at $625 \mathrm{~nm}[19,25]$. These data suggested that for these two enzymes, the second reaction intermediates could be different species. 
In our present study, we have shown that for the $D$. baarsii enzyme, the sharp absorption band at $625 \mathrm{~nm}$ observed at the level of the second transient is not mechanistically informative but results from a photochemical process induced by an excitation due to the Xenon lamp in the 310$345 \mathrm{~nm}$ region. This was shown using different filters between the Xenon lamp and the SOR sample. This sharp band is associated neither with an instrumental artifact nor to the fully reduced/oxidized enzyme but results from specific electronic properties of SOR reaction intermediates and could only be photo-induced by irradiation of a transient at wavelengths below $350 \mathrm{~nm}$. It was demonstrated by the following experiments. i) Pulse radiolysis of a solution without SOR does not present any absorption band in the $625 \mathrm{~nm}$ region, ruling out any instrumental origin for that band. ii) As shown by flash photolysis experiments, SOR alone in its ferrous or ferric state does not conduct to the formation of transient absorption band at $625 \mathrm{~nm}$ when irradiated with a Xenon lamp. iii) The intensity of the sharp absorption band at $625 \mathrm{~nm}$ is directly proportional to the amount of superoxide that reacts with an excess of ferrous SOR. Both reaction intermediates T1 and $\mathrm{T} 2$ are affected by a photochemical process, however the spectrum of $\mathrm{T} 1$ is modified to a lower extent. Its molar absorption coefficient at the maximum of the absorption spectrum $(600 \mathrm{~nm})$ is lowered by a factor of 1.6 in the presence of the $345 \mathrm{~nm}$ filter compared to the $310 \mathrm{~nm}$ filter. This decrease in $\mathrm{T} 1$ absorbance cannot be due to an incomplete reaction of SOR with $\mathrm{O}_{2}{ }^{-}$since both the kinetics and the quantification of the reaction products indicate a stoichiometric reaction of SOR with $\mathrm{O}_{2}{ }^{\circ}$.

Although at this stage it is difficult to determine the exact physical basis for these photochemical processes, it appears that the SOR reaction intermediates possess sensitive absorption bands in the 310-345 $\mathrm{nm}$ region (Figures 1 and 3), which are most likely at the origin of the photochemical processes. In any cases, this study highlights remarkable photochemical properties for these reaction intermediates, which were not previously suspected for iron-peroxide species formed at the SOR active site. Interestingly, the end products remain the same in the presence or in the absence of these photochemical processes and the reaction is always consistent 
with a stoichiometric reduction of superoxide by SOR. Then, these photochemical processes do not modify the overall reaction mechanism of SOR, being transient and without direct chemical reactivity. Further detailed studies would be required to provide a better photochemical/photophysical characterization of this process.

In the absence of these photochemical processes (with the $345 \mathrm{~nm}$ filter) ${ }^{2}$, analysis of the reaction of SOR with superoxide still reveals the presence of two reaction intermediates T1 and T2, $\mathrm{T} 2$ coming from the decay of $\mathrm{T} 1$, with absorbance properties different from those described in the presence of the $310 \mathrm{~nm}$ filter. T2 is finally converted to the final product, the ferric SOR, as shown in equation 2. The values of the rate constants for the formation of T2 $\left(k_{2}\right)$ and its decays $\left(k_{3}\right)$ are very close to each other, 255 and $110 \mathrm{~s}^{-1}$ respectively at $\mathrm{pH} 7.6$, and consequently $\mathrm{T} 2$ spectrum was determined by extrapolations of the kinetic traces (Figure 3). From the results presented here, in the absence of any photochemical process, the reaction mechanism of SOR from $D$. baarsii appears now similar to that reported for the two enzymes from A. fulgidus, with formation of a T2 intermediate associated with a $\mathrm{Fe}^{3+}-\mathrm{OH}$ species $[11,20]$. Moreover, in the SOR from $D$. baarsii, preliminary results indicate that $\mathrm{T} 1$ and $\mathrm{T} 2$ decay exhibited a similar $\mathrm{pH}$ dependency to that of the enzyme from the A. fulgidus (F. Bonnot, C. Houée-Levin, V. Favaudon, V. Nivière, manuscript in preparation). One should note that at $\mathrm{pH} 7.6$, for the two enzymes from A. fulgidus, $k_{2}$ and $k_{3}$ are respectively equal to 3800 and $25 \mathrm{~s}^{-1}$ whereas in $D$. baarsii, they are 255 and $110 \mathrm{~s}^{-1}$. In the case of the D. vulgaris enzyme, which has strong sequence homology with the D. baarsii one, a T2 intermediate was not observed and T1 apparently converts directly to the final oxidized SOR [18]. However, it is possible that in this latter case, a T2 intermediate also exists with however $k_{3}$ much higher than $k_{2}$. In this case, the step described by $k_{2}$ would be rate limiting and $\mathrm{T} 2$ concentration

\footnotetext{
${ }^{2}$ The fact that photochemical processes were observed by pulse radiolysis in the case of the D. baarsii enzyme, but not with the A. fulgidus and D. vulgaris enzymes by different groups could be explained by the following. For instance, the pulse radiolysis devices can be equipped with either Xenon or tungsten lamps and with different filters between the lamp and the sample to be analyzed. These informations are usually not reported in the Materials and Methods section and in general it is not specified which lamp and which filter have been used in each specific pulse radiolysis experiment.
} 
would be very low and not detectable. Then, it is conceivable than the SOR from D. vulgaris exhibits a similar reaction mechanism than that of the enzymes from A. fulgidus and D. baarsii.

In a previous work, we investigated the reaction of the SOR from Treponema pallidum with $\mathrm{O}_{2}{ }^{--}$by pulse radiolysis with a $310 \mathrm{~nm}$ filter and two reaction species were observed [21]. The first one clearly corresponded to the T1 intermediate. However, the spectrum of the second reaction species did not exhibit the sharp absorption band at $625 \mathrm{~nm}$ and looked like that of the final SOR$\mathrm{Fe}^{3+}$ species, with a broad absorbance band at $650 \mathrm{~nm}$. It thus seems that, conversely to the $D$. baarsii enzyme, the $T$. pallidum SOR does not exhibit a photochemical process during the pulse radiolysis with a $310 \mathrm{~nm}$ filter. Its reaction mechanism could be then similar to that of the $D$. vulgaris enzyme, with only one observable reaction intermediate, T1, that decays to the final SOR$\mathrm{Fe}^{3+}$ end product.

In conclusion, the reaction investigated in the absence of photochemical processes for the $D$. baarsii enzyme reveals the formation of a second intermediate which seems similar to that reported for the A. fulgidus enzymes. The data suggest that the reaction mechanism of the different SORs studied so far are very similar, which is in agreement with the strong sequence and structure homologies of their active sites. We are currently reinvestigating the reaction mechanism of the different SOR mutants from D. baarsii, E47A, K48I and E114A, in the absence of photochemical process.

\section{Aknowledgments}

We are grateful to Dr. André Verméglio (CEA-Cadarache, DEVM, Laboratoire de Bioénergétique Cellulaire, France) for the flash photolysis experiments and Izabel Bérard (LSMP, IBS-Grenoble, France) for electrospray mass spectra. 


\section{References}

[1] J.A. Imlay, Cellular defences against superoxide and hydrogen peroxide, Ann. Rev. Biochem. 77 (2008) 755-776.

[2] C.C. Winterbourn, Reconciling the chemistry and biology of reactive oxygen species, Nat. Chem. Biol. 4 (2008) 278-286.

[3] F.E. Jenney Jr., M.F.J.M. Verhagen, X. Cui, M.W.W. Adams, Anaerobic microbes: oxygen detoxification without superoxide dismutase, Science 286 (1999) 306-309.

[4] M. Lombard, M. Fontecave, D. Touati, V. Nivière, Reaction of the desulfoferrodoxin from Desulfoarculus baarsii with superoxide anion. Evidence for a superoxide reductase activity, J. Biol. Chem. 275 (2000) 115-121.

[5] I.A. Abreu, L.M. Saraiva, J. Carita, H. Huber, K.O. Stetter, D.E. Cabelli, M. Teixeira, Oxygen detoxification in the strict anaerobic archaeon Archaeoglobus fulgidus: superoxide scavenging by neelaredoxin, Mol. Microb. 38 (2000) 322-334.

[6] E.D. Coulter, J.P. Emerson, D.M. Kurtz Jr., D.E. Cabelli, Superoxide reactivity of rubredoxin oxidoreductase (desulfoferrodoxin) from Desulfovibrio vulgaris: a pulse radiolysis study, J. Am. Chem. Soc. 122 (2000) 11555-11556.

[7] V. Nivière, M. Fontecave, Discovery of superoxide reductase: an historical perspective, J. Biol. Inorg. Chem. 9 (2004) 119-123.

[8] D.M. Kurtz Jr., Microbial detoxification of superoxide: the non-heme iron reductive paradigm for combating oxidative stress, Acc. Chem. Res. 37 (2004) 902-908.

[9] T. Jovanovic, C. Ascenso, K.R.O. Hazlett, R. Sikkink, C. Krebs, R. Litwiller, L.M. Benson, I. Moura, J.J.G. Moura, J.D. Radolf, B. Huynh, S. Naylor, F. Rusnak, Neelaredoxin, an iron-binding protein from the syphilis spirochete, Treponema pallidum, is a superoxide reductase, J. Biol. Chem. 275 (2000) 28439-28448. 
[10] M. Lombard, D. Touati, M. Fontecave, V. Nivière, Superoxide reductase as a unique defence system against superoxide stress in the microaerophile Treponema pallidum, J. Biol. Chem. 275 (2000) 27021-27026.

[11] J.V. Rodrigues, L.M. Saraiva, I.A. Abreu, M. Teixeira, D.E. Cabelli, Superoxide reduction by Archaeoglobus fulgidus desulfoferrodoxin: comparison with neelaredoxin, J. Biol. Inorg. Chem. 12 (2007) 248-256.

[12] J.P. Emerson, D.E. Cabelli, D.M. Kurtz Jr., An engineered two-iron superoxide reductase lacking the $\left[\mathrm{Fe}(\mathrm{SCys})_{4}\right]$ site retains its catalytic properties in vitro and in vivo, Proc. Natl. Acad. Sc. USA 100 (2003) 3802-3807.

[13] A.P. Yeh, Y. Hu, F.E. Jenney Jr., M.W.W. Adams, D.C. Rees, Structures of the superoxide reductase from Pyrococcus furiosus in the oxidized and reduced states, Biochemistry 39 (2000) 2499-2508.

[14] V. Adams, A. Royant, V. Nivière, F.P. Molina-Heredia, D. Bourgeois, Structure of superoxide reductase bound to ferrocyanide and active site expansion upon X-ray-induced photo-reduction, Structure 12 (2004) 1729-1740.

[15] C. Berthomieu, F. Dupeyrat, M. Fontecave, A. Verméglio, V. Nivière, Redox-dependent structural changes in the superoxide reductase from Desulfoarculus baarsii and Treponema pallidum: a FTIR study, Biochemistry 41 (2002) 10360-10368.

[16] J.P. Emerson, E.D. Coulter, R.S. Phillips, D.M. Kurtz Jr., Kinetics of the superoxide reductase catalytic cycle, J. Biol. Chem. 278 (2003) 39662-39668.

[17] M. Lombard, C. Houée-Levin, D. Touati, M. Fontecave, V. Nivière, Superoxide reductase from Desulfoarculus baarsii: reaction mechanism and role of glutamate 47 and lysine 48 in catalysis, Biochemistry 40 (2001) 5032-5040.

[18] J.P. Emerson, E.D. Coulter, D.E. Cabelli, R.S. Phillips, D.M. Kurtz Jr., Kinetics and mechanism of superoxide reduction by two-iron superoxide reductase from Desulfovibrio vulgaris, Biochemistry 41 (2002) 4348-4357. 
[19] V. Nivière, M. Asso, C.O. Weill, M. Lombard, B. Guigliarelli, V. Favaudon, C. Houée-Levin, Superoxide reductase from Desulfoarculus baarsii: identification of protonation steps in the enzymatic mechanism, Biochemistry 43 (2004) 808-818.

[20] J.V. Rodrigues, I.A. Abreu, D.E. Cabelli, M. Teixeira, Superoxide reduction mechanism of Archaeoglobus fulgidus one-iron superoxide reductase, Biochemistry 45 (2006) 9266-9278.

[21] V. Nivière, M. Lombard, M. Fontecave, C. Houée-Levin, Pulse radiolysis studies on superoxide reductase from Treponema pallidum, FEBS Lett. 497 (2001) 171-173.

[22] V.W. Huang, J.P. Emerson, D.M. Kurtz Jr., Reaction of Desulfovibrio vulgaris two-iron superoxide reductase with superoxide: insights from stopped-flow spectrophotometry, Biochemistry 46 (2007) 11342-11351.

[23] C. Mathé, T.A. Mattioli, O. Horner, M. Lombard, J.M. Latour, M. Fontecave, V. Nivière, Identification of iron(III) peroxo species in the active site of the superoxide reductase SOR from Desulfoarculus baarsii, J. Am. Chem. Soc. 124 (2002) 4966-4967.

[24] C. Mathé, V. Nivière, T.A. Mattioli, $\mathrm{Fe}^{3+}-\eta_{2}$-peroxo species in superoxide reductase from Treponema pallidum. Comparison with Desulfoarculus baarsii, Biophys. Chem. 119 (2006) 38-48.

[25] C. Mathé, C.O. Weill, T.A. Mattioli, C. Berthomieu, C. Houée-Levin, E. Tremey, V. Nivière, Assessing the role of the active-site cysteine ligand in the superoxide reductase from Desulfoarculus baarsii, J. Biol. Chem. 282, (2007) 22207-22216.

[26] G. Katona, P. Carpentier, V. Nivière, P. Amara, V. Adam, J. Ohana, N. Tsanov, D. Bourgeois, Raman-assisted crystallography reveals end-on peroxide intermediates in a nonheme iron enzyme, Science 316 (2007) 449-453.

[27] V. Favaudon, H. Tourbez, C. Houée-Levin, J.M. Lhoste, $\mathrm{CO}_{2}{ }^{--}$radical induced cleavage of disulfide bonds in proteins. A gamma-ray and pulse radiolysis mechanistic investigation, Biochemistry 29 (1990) 10978-10989.

[28] J.W.T. Spinks, R.J. Wood, An Introduction to Radiation Chemistry, 3th edn. John Wiley \& Son., 1990. 
[29] G.V. Buxton, C.R. Stuart, Reevaluation of the thiocyanate dosimeter for pulse-radiolysis, J. Chem. Society-Faraday Trans. 91 (1995) 279-281.

[30] P. Joliot, D. Béal, B. Frilley, A new spectrophotometric method for the study of photosynthetic reactions, J. Chem. Phys. 777 (1980) 209-216.

[31] H.A. Mottola, B.E. Simpson, G. Gorin, Absorptiometric determination of hydrogen peroxide in submicrogram amounts with Leuco crystal violet and peroxidase as catalyst, Anal. Chem. 40 (1970) 410-411.

[32] C. Mathé, V. Nivière, T.A. Mattioli, $\mathrm{Fe}^{3+}$-hydroxide ligation in the superoxide reductase from Desulfoarculus baarsii is associated with $\mathrm{pH}$ dependent spectral changes, J. Am. Chem. Soc. 127 (2005) 16436-16441.

[33] C. Von Sonntag, The Classical Basis of Radiation Biology. Taylor and Francis, London, 1987. 


\section{Figure Legends}

Figure 1. Transient absorption spectrum of the first reaction intermediate formed $100 \mu \mathrm{s}$ after the beginning of the reaction of SOR $\left(100 \mu \mathrm{M}\right.$ in $10 \mathrm{mM}$ formate, $2 \mathrm{mM}$ Tris/ $\mathrm{HCl} \mathrm{pH}$ 7.6) with $\mathrm{O}_{2}{ }^{-}$ $(2.8 \mu \mathrm{M})$, generated by pulse radiolysis. Xenon lamp, (•) with a $310 \mathrm{~nm}$ filter, (o) with a $345 \mathrm{~nm}$ filter.

Figure 2. Kinetic traces during the reaction of the SOR from D. baarsii $(100 \mu \mathrm{M}$ in 10 or $100 \mathrm{mM}$ formate, $2 \mathrm{mM}$ Tris/ $\mathrm{HCl} \mathrm{pH}$ 7.6) with $9 \mu \mathrm{M} \mathrm{O}_{2}{ }^{--}$generated by pulse radiolysis. Top, recorded at $600 \mathrm{~nm}$ in the presence of the $310 \mathrm{~nm}$ filter. Bottom, recorded at $640 \mathrm{~nm}$ in the presence of the 345 nm filter. The dashed lines were calculated for best fit to an exponential model with a rate constant of $500 \mathrm{~s}^{-1}$ (Top) and to a biexponential model with rate constants of 255 and $110 \mathrm{~s}^{-1}$ (Bottom).

Figure 3. Transient absorption spectra, obtained with a Xenon lamp, of the reaction intermediates formed 3-20 ms after the beginning of the reaction of SOR (100 $\mu \mathrm{M}$ in $10 \mathrm{mM}$ formate, $2 \mathrm{mM}$ Tris/HCl $\mathrm{pH}$ 7.6) with $\mathrm{O}_{2}^{\bullet-}(9 \mu \mathrm{M})$, generated by pulse radiolysis. (•) T2 spectrum formed in the presence of a filter cutting off below $310 \mathrm{~nm}, 20 \mathrm{~ms}$ after the pulse. $(\Delta)$ T2 spectrum in the presence of a filter cutting off below $345 \mathrm{~nm}$, calculated from an extrapolation of the decay of $\mathrm{T} 1 \mathrm{using}$ the double exponential fits of the kinetic traces at different wavelengths (o) T3 spectrum formed in the presence of a filter cutting off at $345 \mathrm{~nm}, 20 \mathrm{~ms}$ after the pulse. The solid line shows the spectrum of the solution recorded in an UV-vis spectrophotometer $1 \mathrm{~min}$ after the end of the pulse radiolysis reaction $(20 \mu \mathrm{M}$ SOR in $10 \mathrm{mM}$ formate, $2 \mathrm{mM}$ Tris/ $\mathrm{HCl} \mathrm{pH} 7.6$, reacted with $16.5 \mu \mathrm{M} \mathrm{O}_{2}{ }^{\bullet}$ ), carried out with either a 310 or 354 $\mathrm{nm}$ filter and in the presence of 500 units $/ \mathrm{ml}$ of catalase. 
Figure 4. Variation of the absorption at $625 \mathrm{~nm}$ recorded $20 \mathrm{~ms}$ after the reaction of SOR from $D$. baarsii $(100 \mu \mathrm{M}$ in $10 \mathrm{mM}$ formate, $2 \mathrm{mM}$ Tris/ $\mathrm{HCl} \mathrm{pH} 7.6)$ with increasing concentration of $\mathrm{O}_{2}{ }^{--}$ generated by pulse radiolysis. Xenon lamp with a $310 \mathrm{~nm}$ filter $(\bullet)$ or with a $345 \mathrm{~nm}$ filter (o). 